\title{
Buclizine Hydrochloride
}

National Cancer Institute

\section{Source}

National Cancer Institute. Buclizine Hydrochloride. NCI Thesaurus. Code C65274.

The hydrochloride salt form of buclizine, a piperazine histamine $\mathrm{H} 1$ receptor antagonist with primarily antiemetic and antivertigo activities. Buclizine binds to and blocks the histamine $\mathrm{H} 1$ receptor, thereby preventing the symptoms that are caused by histamine activity. Buclizine exerts its anti-emetic effect by binding to and blocking the muscarinic and histamine receptors in the vomiting center of the central nervous system (CNS). This may prevent activation of the chemoreceptor trigger zone (CTZ) and may reduce nausea and vomiting. 